\title{
Concomitant lipopolysaccharide-induced transfer of blood-derived components including immunoglobulins into milk
}

\author{
M. Lehmann, O. Wellnitz, and R. M. Bruckmaier ${ }^{1}$ \\ Veterinary Physiology, Vetsuisse Faculty University of Bern, Bremgartenstrasse 109a, CH-3001 Bern, Switzerland
}

\begin{abstract}
During a mammary immune response, the integrity of the blood-milk barrier is negatively affected and becomes leaky. The aim of the present study was to demonstrate the blood origin, and to investigate changes in the concentration, of various constituents including immunoglobulins in blood and milk during the early phase of lipopolysaccharide (LPS)-induced mastitis. Five lactating dairy cows received continuous $\beta$-hydroxybutyrate (BHBA) clamp infusions to maintain elevated BHBA blood concentrations (1.5 to $2.0 \mathrm{mmol} / \mathrm{L}$ ) from $48 \mathrm{~h}$ before and $8 \mathrm{~h}$ after LPS administration. One udder quarter was infused with 200 $\mu \mathrm{g}$ of Escherichia coli LPS. A second quarter served as control. Milk and blood samples were taken hourly for $8 \mathrm{~h}$ postchallenge $(\mathrm{PC})$. The somatic cell count in LPS-challenged quarters was increased from $4 \mathrm{~h} \mathrm{PC}$ to the end of the experiment compared with control quarters. In LPS-challenged quarters, L-lactate, BHBA, lactate dehydrogenase $(\mathrm{LDH}), \operatorname{IgG}_{1}$, and $\mathrm{IgG}_{2}$ were increased at $3 \mathrm{~h} \mathrm{PC}$ and remained elevated until the end of experiment ( $8 \mathrm{~h} \mathrm{PC}$ ) compared with control quarters. In addition, the optical density values in milk in a nonquantitative ELISA for antibodies directed against bluetongue virus (used as a measure of nonspecific antibody transfer; all animals were vaccinated) increased and, thus, indicates an increase in these antibodies in response to LPS treatment. L-Lactate concentration also increased in blood $2 \mathrm{~h} \mathrm{PC}$ and in the milk of control quarters during the experiment from $3 \mathrm{~h}$ PC. A second experiment was conducted in vitro to investigate a possible contribution from destructed milk cells to L-lactate concentration and activity of LDH in milk. Aliquots of milk samples $(\mathrm{n}=8)$ were frozen $\left(-20^{\circ} \mathrm{C}\right)$ or disrupted with ultrasound, respectively. Freeze thawing and ultrasound treatment increased LDH in milk samples, but had no effect on L-lactate concentrations. Results suggest that intramammary infusion of LPS induces a systemic response, as evidenced by an eleva-
\end{abstract}

Received February 3, 2012.

Accepted October 23, 2012.

${ }^{1}$ Corresponding author: rupert.bruckmaier@vetsuisse.unibe.ch tion of blood L-lactate concentration. The concomitant changes of all investigated components suggest that they were blood derived. However, the increase in blood components in the milk is not necessarily supportive of the mammary immune system, and likely a side effect of reduced blood-milk barrier integrity.

Key words: blood-milk barrier, immunoglobulin G, lactate, $\beta$-hydroxybutyrate

\section{INTRODUCTION}

In the bovine mammary gland, invading pathogens induce an immune response by stimulating the innate immune system. It is generally accepted that the main effectors of the mammary immune defense against mastitis-causing bacteria are blood derived polymorphonuclear neutrophils (PMN; Burton and Erskine, 2003). Their infiltration into the mammary gland and their accumulation in milk is measured as an increase in the milk SCC, which is widely used as a measure of hygienic milk quality (Harmon, 1994).

During the early acute stage of mammary inflammation a leakage of blood constituents occurs because of an alteration in the blood-milk barrier (Burton and Erskine, 2003). In addition to SCC, the concentrations of several other components change in milk in response to inflammation of the mammary gland, not all of which contribute to host defense.

Milk L-lactate (hereafter referred to as lactate) and the enzyme lactate dehydrogenase (LDH) increase in milk during IMI and have been considered indicators of mastitis, even though the immunological contribution of these factors is not known (Davis et al., 2004; Chagunda et al., 2006). Immunoglobulin $\mathrm{G}$ is the major immunoglobulin in ruminant milk (Butler, 1983) and consists of 2 subclasses: $\operatorname{IgG}_{1}$ and $\operatorname{IgG}_{2}$. Immunoglobulin $G_{1}$ is the predominant antibody type in milk from healthy quarters because of an active, selective $\operatorname{IgG}_{1}$ transport across the blood-milk barrier, likely mediated by the neonatal $\mathrm{Fc}$ receptor $(\mathrm{FcRn})$ receptor system (Baker et al., 2009). In mastitic milk, IgG $\mathrm{I}_{2}$ increases in concentration (Caffin and Poutrel, 1988) and plays a critical role in mammary immune defense against mastitis pathogens (Burton and Erskine, 2003). How- 
ever, antibodies that are not directed against mastitiscausing pathogens are also nonspecifically transferred into the mammary gland and can be found in the milk of healthy udders (e.g., antibodies against the bovine viral diarrhea virus or those against bluetongue virus; Kramps et al., 1999; Kramps et al., 2008). After the bluetongue disease outbreak in Northern Europe in 2006, Swiss cows were vaccinated against the bluetongue virus serotype 8 between 2008 and 2010 .

Another blood constituent without any obvious benefit for immune defense in the mammary gland is the ketone body BHBA, which is produced by the liver. A significant correlation of 0.66 between BHBA in blood and milk was described by Enjalbert et al. (2001); however, information on its possible role in mammary gland health was not provided. Intramammary administration of LPS from Escherichia coli, a common mastitis pathogen, is a well-established method to experimentally induce mastitis under defined conditions for studying the immune response of the mammary gland (Schmitz et al., 2004; Baumert et al., 2009; Wellnitz et al., 2011). In those studies, LPS from different $E$. coli strains were shown to require different concentrations to induce comparable immune responses of the mammary gland. This effect is, besides differences in individual responsiveness, due to variations in the fine structure of LPS (Rietschel et al., 1994).

The objective of the present study was to document changes in milk SCC and lactate, BHBA, $\mathrm{LDH}, \mathrm{IgG}_{1}$, and $\mathrm{IgG}_{2}$ concentrations in milk and to contrast these changes to those in blood during the first hours of LPSinduced mastitis. We hypothesized that the increase in lactate concentration, along with that of other components that are expected to originate from blood, is a result of loss of the integrity of the blood-milk barrier. An additional experiment was performed to establish the origin of lactate in milk.

\section{MATERIALS AND METHODS}

\section{Experiment 1: LPS-Induced Mastitis}

Animals and Management. Five mid-lactation dairy cows (Holstein) in their third to fourth lactation were used in these studies. While maintained in a tiestall, foremilk samples were taken from each quarter approximately 3 wk before, 1 wk before, and immediately before the start of the experiment to verify a constantly low SCC $(<150,000$ cells $/ \mathrm{mL})$. A DeLaval cell counter (DCC; DeLaval International AB, Tumba, Sweden) was used to measure SCC. All cows had been immunized against the bluetongue virus serotype 8 (Bovilis BTV8; Intervet International BV, Boxmeer, the Netherlands) approximately 1 yr before the experiment as a part of a national vaccination campaign.

Experimental Design. DL- $\beta$-Hydroxybutyrate solution (2.14 M; H6501; Sigma-Aldrich, Buchs, Switzerland) was infused $48 \mathrm{~h}$ before and during the LPS challenge to induce hyperketonemia ( 1.5 to $2.0 \mathrm{mmol}$ of BHBA/L in the plasma) throughout the experiment as described by Zarrin et al. (2012). Two intravenous catheters (Cavafix Certo Splittocan; B. Braun Melsungen AG, Melsungen, Germany), one inserted into each jugular vein, were used to infuse BHBA and to take blood samples, respectively.

On the day of challenge and after the morning milking, cows were intramammarily infused with $200 \mu \mathrm{g}$ of $E$. coli LPS into the left front quarter (LPS from E. coli serotype O26:B6; Sigma-Aldrich), diluted in $10 \mathrm{~mL}$ of sterile saline solution $(9 \mathrm{~g} / \mathrm{L})$. The right front quarter was used as a control and treated with $10 \mathrm{~mL}$ of the saline solution. Milk samples $(\sim 20 \mathrm{~mL})$ were hand collected for an immediate SCC measurement that continued hourly for $8 \mathrm{~h}$ postchallenge from the experimental quarters after discarding the first 3 squirts of milk. Milk samples were frozen at $-20^{\circ} \mathrm{C}$ for later analyses. Skim milk was prepared by centrifugation at $4,000 \times g$ for 15 min and milk serum was prepared by centrifugation of the skim milk at $14,000 \times g$ for $30 \mathrm{~min}$.

Blood samples were collected at times coinciding with milk sample collection. Blood was collected into tubes containing FE sodium fluoride/tripotassium EDTA (Greiner Bio-One GmbH, Kremsmünster, Austria) as anticoagulant. Tubes were stored briefly on wet ice and then centrifuged for $20 \mathrm{~min}$ at $3,000 \times g$. Plasma was collected and frozen at $-20^{\circ} \mathrm{C}$ until analyses.

Lactate dehydrogenase activity, lactate concentration, and BHBA concentration were measured in milk serum and blood plasma using the test kits LDH IFCC (Axon Lab AG, Baden, Switzerland), Lactate PAP (bioMérieux SA, Marcy l'Étoile, France) and Ranbut (Randox Laboratories Ltd., London, UK), respectively, with an automated analyzer (Cobas Mira; Roche Diagnostics, Basel, Switzerland) according to the manufacturer's instructions.

The $\operatorname{IgG}_{1}$ and $\mathrm{IgG}_{2}$ concentrations in skim milk and blood plasma were measured using bovine $\operatorname{IgG}_{1}$ and $\mathrm{IgG}_{2}$ ELISA quantitation kits (Bethyl Laboratories Inc., Montgomery, TX) according to the manufacturer`s instructions, with the following slight modifications: after coating of plates overnight with anti-bovine $\operatorname{IgG}_{1} / \operatorname{IgG}_{2}$, the plates were washed using an automatic washing system (microplate washer Columbus Pro; Tecan Group Ltd., Männedorf, Switzerland) and subsequently blocked with $150 \mu \mathrm{L} /$ well of $5 \%$ fish skin gelatin (Sigma-Aldrich) in distilled water for $60 \mathrm{~min}$ at 
room temperature. After washing, $100 \mu \mathrm{L}$ of skim milk diluted in washing buffer $\left(1: 100\right.$ for $\operatorname{IgG}_{2}$ and $1: 1000$ for $\operatorname{IgG}_{1}$ ) or blood plasma samples were added to each well. On the plate, the samples were diluted in 3 serial 1:2 dilutions using a multichannel pipette. One control sample was added to each plate and was used for the calculation of coefficients of variation that reached 10 and $20 \%$ within and between assays, respectively. Plates were incubated for $60 \mathrm{~min}$ at room temperature and subsequently washed as described above. Sheep anti-bovine $\operatorname{IgG}_{1} / \operatorname{IgG}_{2}$ horseradish peroxidase (HRP)conjugated antibody was diluted 1:15,000 and 1:10,000, respectively, in wash buffer and $100 \mu \mathrm{L}$ of this solution was added to each well. The concentrations of $\operatorname{IgG}_{1}$ and $\mathrm{IgG}_{2}$ were calculated by extrapolating from a standard curve generated by a THERMOmax microplate reader (Molecular Devices, Basel, Switzerland).

The ELISA test kit INGEZIM BTV-MILK 12.BTV. K1 (Inmunología y Genética Aplicada SA, Madrid, Spain) was used to determine anti-bluetongue virus antibodies in skim milk according to manufacturer`s instructions. Optical density (OD) values were measured at $450 \mathrm{~nm}$ by using the THERMOmax microplate reader (Molecular Devices).

Data Analysis. Data are presented as means \pm standard error of the mean. Data for SCC, lactate concentration, and LDH activity were log-transformed $\left(\log _{10}\right)$ to improve normality. Differences between LPS and control within each time point and differences between time points within one group were tested for significance $(P<0.05)$ by ANOVA using PROC MIXED of SAS (SAS Institute Inc., Cary, NC; 2002-2008, Release 9.2). The model included time, treatment (LPS or control), the quarter within cow, and their interaction as fixed effects and the cow as repeated subject. For antibodies against anti-bluetongue virus in milk, OD values are presented in a descriptive way.

\section{Experiment 2: Milk Cell Destruction}

Experimental Design. To investigate the effect of milk cell destruction on the lactate concentration and LDH activity in milk, 8 quarter foremilk samples from 2 different cows were collected during 1 morning milking. Three aliquots of each milk sample were treated differently: one aliquot was frozen at $-20^{\circ} \mathrm{C}$, a second was treated with ultrasound for $10 \mathrm{~s}$ at $100 \mathrm{~W}$ (Branson Sonifier 150; Branson Ultrasonics Corp., Danbury, $\mathrm{CT}$ ), and the third served as a control without any treatment (stored in the refrigerator at $4^{\circ} \mathrm{C}$ ). Catalytic activity of LDH and lactate concentration were then detected in milk serum, prepared as described previously, using the test kits LDH IFCC (Axon Lab AG) and Lactate PAP (bioMérieux SA), respectively, in an autoanalyzer (Cobas Mira; Roche Diagnostics) according to the manufacturer's instructions.

Data Analysis. Data are presented as means \pm standard error of the mean. For evaluation of changes of lactate and LDH through freezing and ultrasound, differences between treated and untreated samples were used. Differences between the treatments were tested for significance $(P<0.05)$ by ANOVA using PROC MIXED of SAS (8.02; SAS Institute Inc., Cary, NC). The model included treatment as a fix effect and the sample as repeated subject.

\section{RESULTS}

\section{Experiment 1: LPS-Induced Mastitis}

$\boldsymbol{S C C}$. The SCC started to increase in LPS-treated quarters at $3 \mathrm{~h} \mathrm{PC}$ and was significantly and continuously elevated from $4 \mathrm{~h} \mathrm{PC}$ until the end of the experiment compared with control quarters (Figure 1A). Control quarter SCC was significantly elevated only at $2 \mathrm{~h} \mathrm{PC}$ when compared with $0 \mathrm{~h}$.

Lactate. The lactate concentration in milk of LPStreated and control quarters (Figure 1B) was increased at $3 \mathrm{~h} \mathrm{PC}(P<0.0001$ and $P<0.05$, respectively $)$ and reached concentrations similar to those observed in blood plasma $(>1 \mathrm{~m} M)$ by $6 \mathrm{~h} \mathrm{PC}$, reaching a maximum at $7 \mathrm{~h}$ PC. This increase in lactate was greater in LPStreated quarters compared with control quarters $(P<$ 0.05). In 2 cows, the lactate concentrations in milk of LPS-treated quarters exceeded the values of those in blood. In the blood plasma, lactate concentration was higher at $2 \mathrm{~h} \mathrm{PC}$ compared with the concentration at $0 \mathrm{~h}(P<0.05)$ and continued to increase steadily until the end of the experiment at $8 \mathrm{~h} \mathrm{PC}$.

$\boldsymbol{B H B A}$. In 25 out of 90 milk samples, BHBA concentrations were below the detection limit (Figure 1C). In such cases half of the detection limit $(0.05 \mathrm{mmol} / \mathrm{L})$ was then used as a value for mathematical and statistical calculations. Significantly higher BHBA concentrations were identified in LPS quarters compared with control quarters from $3 \mathrm{~h} \mathrm{PC}$ and continued to increase until the end of the experiment. Control quarter BHBA concentration did not change. The BHBA blood concentration was not analyzed because it was controlled via a BHBA clamp infusion. At $0 \mathrm{~h}$, the BHBA concentration in blood plasma was 16 -fold higher $(P<$ 0.05) than in the milk. During the experiment, this ratio diminished to a 3 -fold difference at $8 \mathrm{~h} \mathrm{PC}$, but did not reach the blood plasma concentrations during the experiment.

$\boldsymbol{L D H}$. The LDH activity in milk of LPS-treated quarters (Figure 1D) was significantly higher at $3 \mathrm{~h} \mathrm{PC}$ compared with control quarters and remained elevated 

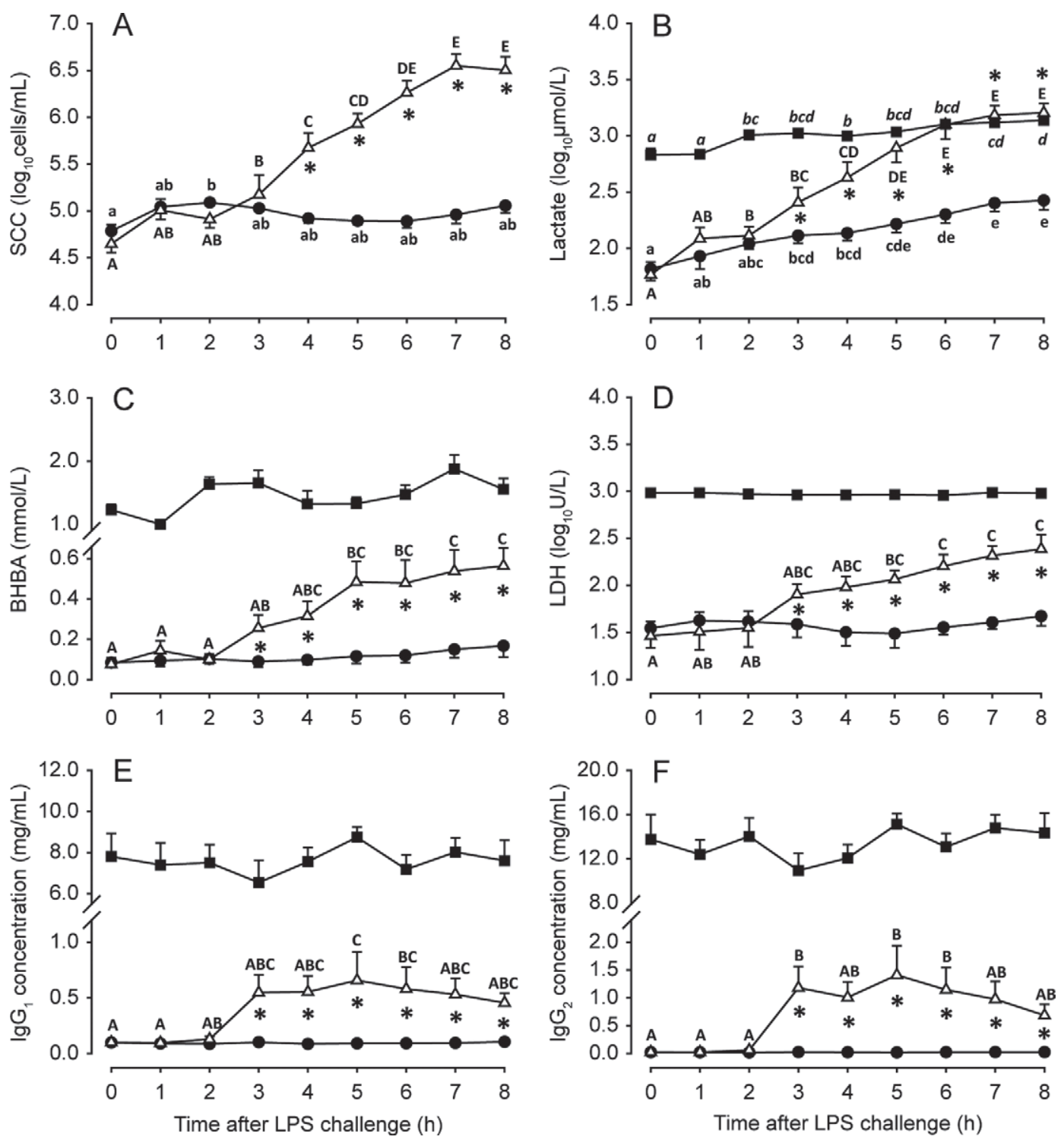

Figure 1. Milk SCC (A), lactate (B), BHBA (C), lactate dehydrogenase (LDH; D), $\operatorname{IgG}_{1}(\mathrm{E})$, and $\operatorname{IgG}_{2}(\mathrm{~F})$ concentrations in milk of control quarters $(\bullet)$, LPS-challenged quarters $(\Delta)$, and in the blood plasma $(\mathbf{\square})$ of 5 cows. ${ }^{*}$ indicates a significant $(P<0.05)$ difference between LPS and control quarters within each time point. Different lowercase letters (a-e) indicate significant differences between time points within control quarters; different uppercase letters (A-E) indicate significant differences between time points within LPS-challenged quarters; no letters indicate no differences between time points. Data are presented as means \pm SEM of 5 cows.

until the end of the experiment, but did not reach the concentrations found in blood. The activity of LDH in blood plasma and milk from control quarters did not change throughout the experiment. At $0 \mathrm{~h}$, the blood/ milk LDH ratio was 29:1, decreasing during the experiment to $3: 1$ at $8 \mathrm{~h} \mathrm{PC}$.

$\boldsymbol{I g} \boldsymbol{G}_{\boldsymbol{1}}$ and $\boldsymbol{I g} \boldsymbol{G}_{2}$. From 3 to $8 \mathrm{~h} \mathrm{PC,} \operatorname{IgG}_{1}$ and $\operatorname{IgG}_{2}$ concentrations in milk of LPS-treated quarters were significantly higher compared with control quarters (Figure $1 \mathrm{E}$ and $1 \mathrm{~F}$ ). No changes in IgG1 and IgG2 concentrations in blood plasma and milk of control quarters could be detected throughout the experiment.
The blood:milk $\operatorname{IgG} 1$ and $\operatorname{IgG}_{2}$ ratios were $77: 1$ and 554:1, respectively, before LPS challenge. At $8 \mathrm{~h}$ PC the blood:milk $\operatorname{IgG}_{1}$ and $\operatorname{IgG}_{2}$ ratios diminished to $17: 1$ and $21: 1$, respectively. In addition, the ratio of IgG1:IgG2 in blood plasma and milk of treated and control quarters was calculated throughout the experiment (Figure 2). At $0 \mathrm{~h}$, the ratio in milk from both treated and control quarters was approximately 4 , whereas in blood, the ratio was 0.48 . In the blood plasma, the ratio $\operatorname{IgG}_{1}: \operatorname{IgG}_{2}$ was 1.0:2.1 and did not change throughout the experiment. In the milk of the LPS-treated quarter, the ratio started to decrease at $2 \mathrm{~h}$, and reached the level in 


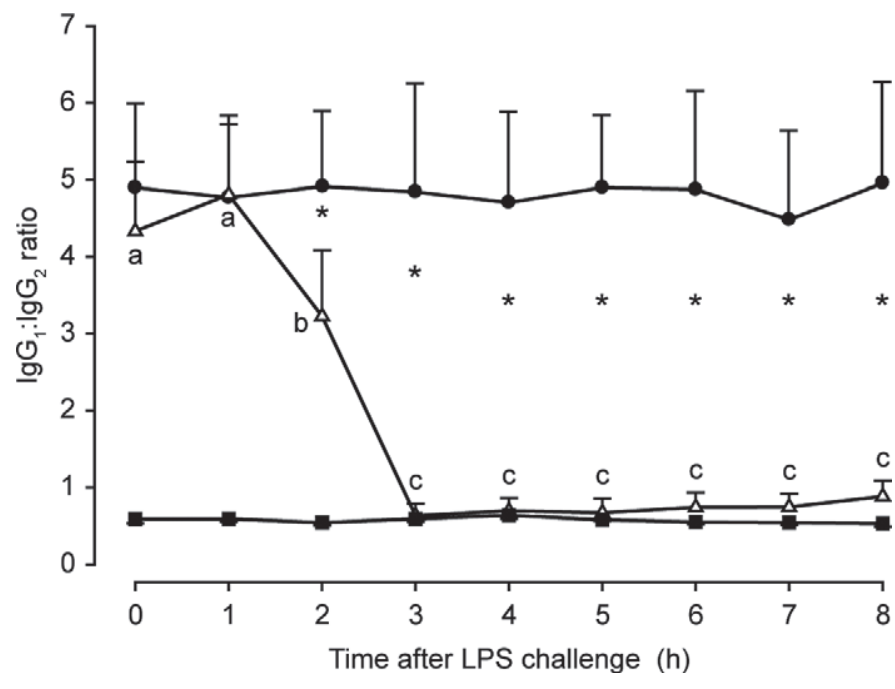

Figure 2. Ratios of $\operatorname{IgG}_{1}: \operatorname{IgG}_{2}$ in blood plasma (ם) and milk of control quarters $(\bullet)$ and LPS-challenged $(\Delta)$ quarters. * indicates a significant $(P<0.05)$ difference between LPS and control quarters within each time point. Different letters $(\mathrm{a}-\mathrm{c})$ indicate significant differences between time points within LPS-treated quarters; no letters indicate no differences between time points (control quarters and blood plasma). Data are presented as means \pm SEM of 5 cows.

blood plasma at $3 \mathrm{~h} \mathrm{PC}$, which was maintained until the end of experiment.

Anti-Bluetongue Virus Antibodies. The nonquantitative test indicated that all examined milk samples were positive for anti-bluetongue virus antibodies (cut-off OD value for a positive result was 0.38 ). The $\mathrm{OD}$ values between 0 and $2 \mathrm{~h} \mathrm{PC}$ ranged from 0.89 to 1.46 in control quarters and from 0.87 to 1.49 in LPSchallenged quarters. Between 3 and $8 \mathrm{~h} \mathrm{PC}$, the OD values ranged from 0.92 to 1.46 in control quarters but from 1.17 to 1.74 in LPS challenged quarters.

\section{Experiment 2: Milk Cell Destruction}

Freezing and thawing and ultrasound treatment significantly increased the catalytic activity of $\mathrm{LDH}$ in milk by 44 and $50 \%$, respectively. Freezing and thawing and ultrasound treatment had no effect on lactate concentrations in milk. (Figure 3)

\section{DISCUSSION}

In the present study, changes in various blood and milk components were quantified during the early phase of LPS-induced mastitis. The observed increase in SCC in response to intramammary LPS challenge has been shown before (Baumert et al., 2009; Wellnitz et al., 2011). The slight increase in SCC in the 2 first hours in all quarters was also expected and regularly observed after milking (Wellnitz et al., 2011). Coinciding with the infiltration of PMN, the blood-milk barrier is expected to become leaky, allowing blood constituents to enter the lumen (Burton and Erskine, 2003) or, as has been shown for lactose, exit the lumen and enter the circulation (Bruckmaier et al., 2004).

The hypothesis that increased passage of blood constituents into milk occurs during mammary inflammation was supported by the present study. The increasing BHBA concentration in milk after LPS challenge must have been blood derived because it occurred only in animals that received a BHBA infusion to keep blood BHBA concentrations constantly elevated throughout the experiment. In cows with normal BHBA blood concentrations, the concentration in milk remained below the detection limit for both LPS-treated and control quarters $(0.1 \mathrm{mmol} / \mathrm{L}$; data not shown $)$. The


Figure 3. Lactate concentration (A) and lactate dehydrogenase $(\mathrm{LDH})$ activity $(\mathrm{B})$ after different treatments (control, $-20^{\circ} \mathrm{C}$, and ultrasound) of quarter foremilk samples $(\mathrm{n}=8) .{ }^{*}$ indicates a significant difference $(P<0.05)$ between freezing or ultrasound treatment and control. Data are presented as means \pm SEM of 8 samples. 
accumulation of BHBA in milk of LPS-treated quarters suggests that LPS-induced mastitis causes a loss of the blood-milk barrier integrity (Bannerman et al., 2004) and allows the BHBA molecules to pass through the barrier and to accumulate in milk. These results are in agreement with Nielsen et al. (2005) who found higher BHBA milk concentrations in diseased quarters compared with healthy quarters. The other investigated parameters lactate, $\mathrm{LDH}$, and immunoglobulins started to increase at the same time after LPS challenge as BHBA, which indicated that also these factors do, at least in part, originate from blood.

Experiment 2 showed that milk cell disruption (by freezing or by ultrasound) leads to increased LDH activity in milk, which is in agreement with earlier studies (Kato et al., 1989; Lipperheide et al., 1995) whereas lactate did not significantly change. Milk LDH activity was thought to originate from the blood and to be a suitable indicator of increased permeability of the blood-milk barrier (Symons and Wright, 1974). In experiment 1, the blood:milk LDH ratio decreased in response to LPS challenge in a similar manner to that observed for BHBA, yet milk concentrations did not reach those observed in blood within the experimental period. This is possibly due to the large difference in the molecular weights (140 vs. $104 \mathrm{kDa})$. Our current finding suggests that the origin of LDH in milk may be attributable to both soluble LDH from blood as well as disrupted leukocytes (Kato et al., 1989) and epithelial cells (Bogin et al., 1977; Zank and Schlatterer, 1998).

Lactate is known to increase in milk during mastitis (Davis et al., 2004). However, the origin of the lactate remained unclear. Our data demonstrated that lactate concentration increased also in blood in response to intramammary LPS administration. Intravenous LPS administration has been shown to increase blood lactate concentrations in cows (Giri et al., 1990). In the present study, lactate concentrations in milk of control quarters increased slightly but concomitantly with blood lactate concentration. This is in contrast to SCC, BHBA, LDH, $\mathrm{IgG}_{1}, \mathrm{IgG}_{2}$, and anti-bluetongue virus antibodies, which remained relatively stable in blood. This underlines the suggestion that the majority of lactate in healthy quarters originates from blood.

Lactate concentrations in milk of LPS-treated quarters increased to comparable levels to those in blood plasma (at $6 \mathrm{~h} \mathrm{PC}$ ), and, surprisingly, in 2 cows the concentrations of lactate in milk of LPS-treated quarters exceeded the concentrations of lactate in blood. This is in contrast to the concentrations of BHBA and LDH, which were always higher in blood than in milk. This observation may be explained by additional lactate production and release during anaerobic metabolism by milk and epithelial cells in the gland (Mayer et al., 1988; Silanikove et al., 2011), whereas the results of experiment 2 show that the lactate produced by cells in the milk appeared to be released from these cells directly after synthesis. In addition, the small size of the lactate molecule (90 Da) as compared with the other investigated constituents may allow for increased transfer from blood into milk. The existence of a specific transmembrane transport mechanism for lactate via aquaporins is likely, as aquaporins transport lactate (Conde et al., 2010), and aquaporins are present in the bovine mammary gland (Mobasheri et al., 2011).

In the present study, $\operatorname{IgG}_{1}$ was the predominant $\operatorname{IgG}$ antibody subclass in milk before LPS challenge, which is in agreement with earlier studies (Guidry et al., 1980; Butler, 1983). It is likely that the specific transport mechanism for $\operatorname{IgG}_{1}$, which is prevalent in prepartum colostrum formation, remains weakly expressed during lactation. Both $\operatorname{IgG}_{1}$ and $\operatorname{IgG}_{2}$ increased simultaneously $3 \mathrm{~h}$ after intramammary LPS challenge and the $\mathrm{IgG}_{1}: \mathrm{IgG}_{2}$ ratio reached a similar milk ratio to that observed in blood. Immunoglobulin $\mathrm{G}_{2}$ is considered to be the main opsonic antibody for neutrophil phagocytosis and is, therefore, most important for mammary immune defense against mastitis pathogens (Hill et al., 1983; Leitner et al., 2000). Both $\operatorname{IgG}_{1}$ and $\operatorname{IgG}_{2}$ milk concentrations increased $3 \mathrm{~h} \mathrm{PC}$, along with SCC, BHBA, LDH, and lactate, indicating an unspecific transfer through the opening of the blood-milk barrier.

The results of the ELISA used for the detection of antibodies against bluetongue virus in milk can be interpreted solely as positive, doubtful, or negative according to the manufacturer. However, the higher OD values measured in milk of LPS-challenged quarters after $3 \mathrm{~h} \mathrm{PC}$ indicate an increase in antibodies against bluetongue virus. Thus, a nonspecific accumulation of various antibodies in the mammary gland during mastitis is likely. Obviously, during the alteration of the blood-milk barrier, antibodies, regardless of specificity, are able to pass the blood-milk barrier. This is in agreement with Charlier et al. (2006) who found higher Ostertagia ostertagi antibody levels in milk of experimentally infected quarters. They described that an acute mastitis causes a flow of specific and nonspecific antibodies from blood into milk. These finding could be important to understand the effectiveness of vaccinations against mastitis pathogens.

\section{CONCLUSIONS}

All investigated parameters appear to be blood derived and their increase in milk occurs in parallel with the increase in SCC. The integrity of the blood-milk barrier is reduced during the early phase of LPS-induced mastitis. This allows various blood constituents 
to pass through the blood-milk barrier to milk, which may or may not support the mammary immune response. Intramammary LPS infusion also induces a systemic immune reaction, shown by our evidence of an increase in blood lactate concentration that affects the lactate in milk of control quarters. The increase of some specific IgG in milk during mammary immune response may not be supportive for the mammary immune system and is, at least partially, just a result of reduced integrity of the blood-milk barrier. However, these results show that the degree to which the blood-milk barrier integrity is compromised by a mastitis pathogen influences the milk composition and content of blood components. The combat against mastitis pathogens may be improved by the alteration of the blood-milk barrier, especially if specific antibodies are present in the blood.

\section{ACKNOWLEDGMENTS}

We gratefully acknowledge the work of $\mathrm{H}$. Anette van Dorland, Martin C. M. B. Vernay, Mousa Zarrin, and Luisa De Matteis during the experiment and Yolande Zbinden for her excellent technical assistance (all of University of Bern, Bern, Switzerland). The valuable scientific input of Wolfgang Steinberg and Christian Frank (DSM Nutritional Products, Basel, Switzerland) and of Thomas Foerster and Markus Huetter (FoersterTechnik GmbH, Engen, Germany) is gratefully appreciated. This study was supported by DSM Nutritional Products and in part by the Swiss National Science Foundation (Bern, Switzerland; grant no. 320030120317).

\section{REFERENCES}

Baker, K., S.-W. Qiao, T. Kuo, K. Kobayashi, M. Yoshida, W. I. Lencer, and R. S. Blumberg. 2009. Immune and non-immune functions of the (not so) neonatal Fc receptor, FcRn. Semin. Immunopathol. 31:223-236.

Bannerman, D. D., M. J. Paape, J.-W. Lee, X. Zhao, J. C. Hope, and P. Rainard. 2004. Escherichia coli and Staphylococcus aureus elicit differential innate immune responses following intramammary infection. Clin. Diagn. Lab. Immunol. 11:463-472.

Baumert, A., R. M. Bruckmaier, and O. Wellnitz. 2009. Dose dependant SCC changes after intramammary lipopolysaccharide challenge. Milchwissenschaft 64:119-121.

Bogin, E., G. Ziv, J. Avidar, B. Rivetz, S. Gordin, and A. Saran. 1977. Distribution of lactate dehydrogenase isoenzymes in normal and inflamed bovine udders and milk. Res. Vet. Sci. 22:198-200.

Bruckmaier, R. M., C. E. Ontsouka, and J. W. Blum. 2004. Fractionized milk composition in dairy cows with subclinical mastitis. Vet. Med. - Czech 49:283-290.

Burton, J. L., and R. J. Erskine. 2003. Immunity and mastitis some new ideas for an old disease. Vet. Clin. North Am. Food Anim. Pract. 19:1-45.

Butler, J. E. 1983. Bovine immunoglobulins: An augmented review. Vet. Immunol. Immunopathol. 4:43-152.
Caffin, J. P., and B. Poutrel. 1988. Physiological and pathological factors influencing bovine immunoglobulin $\mathrm{G}_{2}$ concentration in milk. J. Dairy Sci. 71:2035-2043.

Chagunda, M. G. G., T. Larsen, M. Bjerring, and K. L. Ingvartsen. 2006. L-Lactate dehydrogenase and N-acetyl- $\beta$-D-glucosaminidase activities in bovine milk as indicators of non-specific mastitis. J. Dairy Res. 73:431-440.

Charlier, J., L. Duchateau, F. Vangroenweghe, E. Claerebout, C. Burvenich, and J. Vercruysse. 2006. The effect of an experimentally induced acute mastitis on the test results of an Ostertagia ostertagi milk ELISA. Vet. Parasitol. 136:161-165.

Conde, A., G. Diallinas, F. Chaumont, M. Chaves, and H. Gerós. 2010. Transporters, channels, or simple diffusion? Dogmas, atypical roles and complexity in transport systems. Int. J. Biochem. Cell Biol. 42:857-868.

Davis, S. R., V. C. Farr, C. G. Prosser, G. D. Nicholas, S. Turner, J. Lee, and A. L. Hart. 2004. Milk L-lactate concentration is increased during mastitis. J. Dairy Res. 71:175-181.

Enjalbert, F., M. C. Nicot, C. Bayourthe, and R. Moncoulon. 2001. Ketone bodies in milk and blood of dairy cows: Relationship between concentrations and utilization for detection of subclinical ketosis. J. Dairy Sci. 84:583-589.

Giri, S. N., P. Emau, J. S. Cullor, G. H. Stabenfeldt, M. L. Bruss, R. H. Bondurant, and B. I. Osburn. 1990. Effects of endotoxin infusion on circulating levels of eicosanoids, progesterone, cortisol, glucose and lactic acid, and abortion in pregnant cows. Vet. Microbiol. 21:211-231.

Guidry, A. J., J. E. Butler, R. E. Pearson, and B. T. Weinland. 1980. $\operatorname{IgA}, \operatorname{IgG}_{1}, \operatorname{IgG}_{2}, \operatorname{IgM}$, and BSA in serum and mammary secretion throughout lactation. Vet. Immunol. Immunopathol. 1:329-341.

Harmon, R. J. 1994. Physiology of mastitis and factors affecting somatic cell counts. J. Dairy Sci. 77:2103-2112.

Hill, A. W., D. J. Heneghan, T. R. Field, and M. R. Williams. 1983. Increase in specific opsonic activity in bovine milk following experimental Escherichia coli mastitis. Res. Vet. Sci. 35:222-226.

Kato, K., K. Mori, and N. Katoh. 1989. Contribution of leukocytes to the origin of lactate dehydrogenase isozymes in milk of bovine mastitis. Nihon Juigaku Zasshi 51:530-539.

Kramps, J. A., C. van Maanen, G. van de Wetering, G. Stienstra, S. Quak, J. Brinkhof, L. Rønsholt, and B. Nylin. 1999. A simple, rapid and reliable enzyme-linked immunosorbent assay for the detection of bovine virus diarrhoea virus (BVDV) specific antibodies in cattle serum, plasma and bulk milk. Vet. Microbiol. 64:135-144.

Kramps, J. A., K. van Maanen, M. H. Mars, J. K. Popma, and P. A. van Rijn. 2008. Validation of a commercial ELISA for the detection of bluetongue virus (BTV)-specific antibodies in individual milk samples of Dutch dairy cows. Vet. Microbiol. 130:80-87.

Leitner, G., B. Yadlin, A. Glickman, M. Chaffer, and A. Saran. 2000. Systemic and local immune response of cows to intramammary infection with Staphylococcus aureus. Res. Vet. Sci. 69:181-184.

Lipperheide, C., R. Andersson, B. Petersen, and H. Sommer. 1995. Determination of lactate dehydrogenase activity and urea content in milk by dry chemistry. Zentralbl. Veterinarmed. A 42:221-225.

Maver, S. J., A. E. Waterman, P. M. Keen, N. Craven, and F. J. Bourne. 1988. Oxygen concentration in milk of healthy and mastitic cows and implications of low oxygen tension for the killing of Staphylococcus aureus by bovine neutrophils. J. Dairy Res. $55: 513-519$.

Mobasheri, A., B. H. Kendall, J. E. J. Maxwell, A. V. Sawran, A. J. German, D. Marples, M. R. Luck, and M. D. Royal. 2011. Cellular localization of aquaporins along the secretory pathway of the lactating bovine mammary gland: An immunohistochemical study. Acta Histochem. 113:137-149.

Nielsen, N. I., T. Larsen, M. Bjerring, and K. L. Ingvartsen. 2005. Quarter health, milking interval, and sampling time during milking affect the concentration of milk constituents. J. Dairy Sci. 88:3186-3200.

Rietschel, E. T., T. Kirikae, F. U. Schade, U. Mamat, G. Schmidt, H. Loppnow, A. J. Ulmer, U. Zähringer, U. Seydel, F. Di Padova, M. Schreier, and H. Brade. 1994. Bacterial endotoxin: Molecu- 
lar relationships of structure to activity and function. FASEB J. $8: 217-225$.

Schmitz, S., M. W. Pfaffl, H. H. D. Meyer, and R. M. Bruckmaier. 2004. Short-term changes of mRNA expression of various inflammatory factors and milk proteins in mammary tissue during LPSinduced mastitis. Domest. Anim. Endocrinol. 26:111-126.

Silanikove, N., A. Rauch-Cohen, F. Shapiro, S. Blum, A. Arieli, and G. Leitner. 2011. Lipopolysaccharide challenge of the mammary gland in bovine induced a transient glandular shift to anaerobic metabolism. J. Dairy Sci. 94:4468-4475.

Symons, D. B. A., and L. J. Wright. 1974. Changes in bovine mammary gland permeability after intramammary exotoxin infusion. J. Comp. Pathol. 84:9-17.
Wellnitz, O., E. T. Arnold, and R. M. Bruckmaier. 2011. Lipopolysaccharide and lipoteichoic acid induce different immune responses in the bovine mammary gland. J. Dairy Sci. 94:5405-5412.

Zank, W., and B. Schlatterer. 1998. Assessment of subacute mammary inflammation by soluble biomarkers in comparison to somatic cell counts in quarter milk samples from dairy cows. Zentralbl. Veterinarmed. A 45:41-51.

Zarrin, M., L. De Matteis, M. C. M. B. Vernay, C. Morel, O. Wellnitz, H. A. van Dorland, and R. M. Bruckmaier. 2012. Effects of longterm hyperketonemia on metabolism and performance in lactating dairy cows. J. Dairy Sci. 95(Suppl. 2):703. (Abstr.) 